\title{
CONVERSION OF QUINOLINE ON ReS, CATALYSTS: EFFECT OF THE SUPPORT AND THE ADDITION OF CS IN THE FEED
}

\author{
ROMINA BASSI ${ }^{a}$, ESTEBAN CAMÚ ${ }^{a}$, MIRZA VILLARROEL ${ }^{b}$, FCO. JAVIER GIL-LLAMBÍAS ${ }^{b}$, J. L. GARCÍA-FIERRO , \\ NÉSTOR ESCALONA ${ }^{d, e, f}$, PATRICIO BAEZA $A^{a^{*}}$
}

\author{
${ }^{a}$ Pontificia Universidad Católica de Valparaíso, Valparaíso, Chile, Casilla 4059. \\ ${ }^{b}$ Universidad de Santiago de Chile, Facultad de Química y Biología, Santiago, Chile. \\ 'Instituto de Catálisis y Petroleoquímica, CSIC, Campus UAM, 28049 Madrid, España.

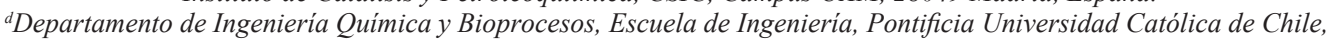 \\ Avenida Vicuña Mackenna 4860, Macul, Santiago, Chile. \\ e Departamento de Química Física, Facultad de Químicas, Pontificia Universidad Católica de Chile.
}

${ }^{f}$ Centro de Investigación en Nanotecnología y Materiales Avanzados (CIEN-UC), Pontificia Universidad Católica de Chile, Santiago, Chile.

\section{ABSTRACT}

The effect of supports and the addition of $\mathrm{CS}_{2}$ in the feed were studied on hydrodenitrogenation of Quinoline in a continuous flow reactor over ReS ${ }_{2}$ support catalysts at 300,325 and $350{ }^{\circ} \mathrm{C}$ and $3 \mathrm{MPa}$ of $\mathrm{H}_{2}$. The $\mathrm{ReS}_{2}$ supported on $\mathrm{TiO}_{2}$ displayed the highest activity followed by $\mathrm{ZrO}_{2}, \gamma-\mathrm{Al}_{2} \mathrm{O}_{3}$ and $\mathrm{SiO}{ }_{2}$ supports. The activity trend was correlated with the Re dispersion on the support. The effect of the addition of $\mathrm{CS}_{2}$ was increased activity until $2.5 \mathrm{v} / \mathrm{v} \% \mathrm{content}$. At higher $\mathrm{CS}_{2}$ content the activity decreased due to competitive adsorption between $\mathrm{CS}_{2}$ and Quinoline on the active sites.

Keywords: Quinoline, support, Carbon sulphide.

\section{INTRODUCTION}

The quality of crude oil decreases with content of heavier sulphur and nitrogen organic compounds that hinder hydrotreatment processes (HT), particularly hydrodesulphurisation (HDS) and hydrodenitrogenation (HDN). Moreover, stringent environmental regulations have forced the oil industry to reduce the sulphur and nitrogen levels present in fuels. In order to meet the required standards, it is essential to find more active catalysts than the typical $\mathrm{HT} \mathrm{Ni}(\mathrm{Co})-\mathrm{Mo} / \mathrm{Al}_{2} \mathrm{O}_{3}$ ones. In this context, several research studies have been carried out in an attempt to either improve the activity of classical sulphide catalysts or find alternative catalysts ${ }^{1-3}$.

In recent years there have been various investigations into HDN, since the nitrogen molecules present in oil produce a poisoning of the catalysts used in other oil refining processes ${ }^{4}$, and mainly because these molecules inhibit HDS and other HT processes ${ }^{5}$.

In this context, Eijsbouts et al. ${ }^{6}$ studied the reactivity of first-, second-, and third-row transition metal sulphide (TMS) supported on activated carbon in the HDN of Quinoline. They found that the first-row transition metal sulphides displayed low Quinoline conversion to hydrocarbons, while the second- and third-row TMS formed a volcanic curve with maximum at $\mathrm{Rh} / \mathrm{C}$ and $\mathrm{Ir} / \mathrm{C}$ catalysts, respectively. On this curve, $\mathrm{Re} / \mathrm{C}$ presented intermediate activity but with high selectivity for propylbenzene. The $\mathrm{ReS}_{2}$ catalyst has been studied rarely with $\mathrm{HDN}$ reactions, though a $\mathrm{ReS}_{2} / \mathrm{Al}_{2} \mathrm{O}_{3}$ catalyst exhibited higher activity ( 1.6 times) than the $\mathrm{Ni}-\mathrm{Mo} / \mathrm{Al}_{2} \mathrm{O}_{3}$ catalyst in the HDS of thiophene ${ }^{7}$.

Considering the high activity of $\mathrm{ReS}_{2}$ in the HDS, the objectives of the present study was to analyse the effect of the support $\left(\mathrm{TiO}_{2}, \mathrm{ZrO}_{2}, \mathrm{SiO}_{2}\right.$ and $\gamma-\mathrm{Al}_{2} \mathrm{O}_{3}$ on the HDN of Quinoline using catalytic systems based on rhenium sulphide, and to evaluate the effect of adding $\mathrm{CS}_{2}$ into the feed, due to the absence of $\mathrm{H}_{2} \mathrm{~S}$ as reaction product, to stabilize the active sites.

\section{EXPERIMENTAL}

2.1 Preparation of the catalysts

The rhenium catalysts supported on $\gamma-\mathrm{Al}_{2} \mathrm{O}_{3}$ (BASF D10-10), $\mathrm{ZrO}_{2}, \mathrm{TiO}_{2}$ (P-25 Degussa) and $\mathrm{SiO}$ (BASF D10-11) were prepared by wet impregnation using $\mathrm{NH}_{4} \mathrm{ReO}_{4}$ (Aldrich, 99\%) as the precursor salt. The $\mathrm{ZrO}_{2}$ support was obtained by direct calcination of commercial hydrated zirconia, $\mathrm{Zr}(\mathrm{OH})_{4}(\mathrm{MEL}$ Chemicals) at $573 \mathrm{~K}$ for 3 hours. The nominal metal content was $2.7 \mathrm{at} \mathrm{nm}^{-2}$. The impregnated catalysts were left to soak at room temperature for $24 \mathrm{~h}$. They were then dried at $393 \mathrm{~K}$ for $12 \mathrm{~h}$ and finally calcined at $573 \mathrm{~K}$ for $0.5 \mathrm{~h}$.

2.2 Characterisation of the catalysts

The BET specific surface areas $\left(\mathrm{S}_{\mathrm{BET}}\right)$ and pore volumes of the samples were determined using Micromeritics-TriStar II 3020. X-ray powder diffraction patterns were obtained using a Rigaku diffractometer. The total acidity measurements of sulfide catalysts were carried out by potentiometric titration [8]. X-ray photoelectron spectra (XPS) of sulfide catalysts before and after reaction were recorded on a VG Escalab 200R electron spectrometer. Details of the experimental procedure have been reported in a previous work ${ }^{9}$. 2.2 Catalytic Activity

The Quinoline conversion reaction was carried out in a continuous flow micro-reactor, with the following reactor load: $0.2 \mathrm{~g}$ of the catalyst $\operatorname{Re}(2,7) / \gamma$ $\mathrm{Al}_{2} \mathrm{O}_{3}, \mathrm{Re}(2,7) / \mathrm{ZrO}_{2}, \mathrm{Re}(2,7) / \mathrm{TiO}$ or $\mathrm{Re}(2,7) / \mathrm{SiO}_{2}$, diluted at a ratio of $1: 1$ $\mathrm{v} / \mathrm{v}$ with $\mathrm{SiO}_{2}$ (BASF D11-10). The remainder of the reactor was filled with $\mathrm{SiC}$. The catalysts were subjected to an in-situ pre-sulphurization treatment at $623 \mathrm{~K}$ for 4 hours. The catalytic reaction was then carried out under conditions similar to industry standards at reaction temperature of $573 \mathrm{~K}$, with a feed of $5000 \mathrm{ppmv}$ of Quinoline at a flow rate of $0.1 \mathrm{~mL} \mathrm{~min}^{-1}$ and $3 \mathrm{MPa}$ of $\mathrm{H}_{2}$. The samples were analysed by GC-FID once a steady state had been reached. In order to evaluate the effect of $\mathrm{CS}_{2}$ on the HDN of Quinoline, $\operatorname{Re}(2,7) / \gamma-\mathrm{Al}_{2} \mathrm{O}_{3}$ was used as the catalyst, and the feed was altered with three concentrations of $\mathrm{CS}_{2} 2.5 \%, 5 \%$ and $10 \% \mathrm{v} / \mathrm{v}$.

In order to compare the results for Quinoline conversion on the different supports, the specific rate (r) was calculated using the rate integral equation assuming pseudo-first order in the quinoline, in accordance with the following equation:

$$
r=k * C_{o}=-\frac{F_{o}}{m} * \ln (1-\tau)
$$

This kinetic equation is designated the first order integral equation, in which the reaction rate is in unit of $\mathrm{mol} \mathrm{g}^{-1} \mathrm{~s}^{-1}, \tau$ is the level of conversion, $m$ the mass of the catalyst $(\mathrm{g})$ and $F_{O}$ is the molar flow $\left(\mathrm{mol} \mathrm{s}^{-1}\right)$.

The intrinsic rate, $r_{i}$, represents the molecules of quinoline transformed by the Re atoms per second (molec. at. $\mathrm{Re}^{-1} \mathrm{~s}^{-1}$ ), and was calculated using the following equation:

$$
r_{i}=\frac{r}{N_{R e}} * N a v
$$

Where $\mathrm{N}_{\mathrm{Re}}$ are the Re atoms per gram of catalyst per $\mathrm{nm}^{2}$ of support, $\mathrm{r}$ is the rate and Nav is Avogadro's number.

\section{RESULTS AND DISCUSSION}

3.1 Characterisation of the supports and catalysts

Table 1 shows the results for the textural properties of the supports and catalysts samples obtained from $\mathrm{N}_{2}$ isotherms and the total acid strength of the sulphide catalysts. These results show a decrease in specific surface area and total pore volume with Re impregnation. This decrease is almost proportional 
to the Re charge, suggesting that there is no significant pore blocking on the supports. The acidic strength was found in accordance with the criteria proposed by Cid and $\mathrm{Pecchi}^{8}$, and follows the following trend: $\mathrm{ReS}_{2} / \gamma-\mathrm{Al}_{2} \mathrm{O}_{3}$ $>\mathrm{ReS}_{2} / \mathrm{SiO}_{2}>\mathrm{ReS} / \mathrm{TiO}_{2}>\mathrm{ReS}_{2} / \mathrm{ZrO}_{2}$. For this trend, $\mathrm{E}_{0}>100$ are for very strongly acidic sites, $0<\mathrm{E}_{0}<100$ means strongly acidic sites, $0>\mathrm{E}_{0}>-100$ is for weakly acidic sites and $\mathrm{E}_{0}<-100$ means very weak acidic sites. Therefore, the results show that the catalyst $\mathrm{ReS} / \gamma-\mathrm{Al}_{2} \mathrm{O}_{3}$ has weak acidic sites, while the other catalysts present very weak acidic sites.

Table 1. Composition, textural properties and acidic strength of the supports and catalysts.

\begin{tabular}{|c|c|c|c|c|}
\hline Samples & $\begin{array}{c}\mathbf{R e} \\
\begin{array}{c}\text { Nominal content } \\
\left(\text { at. } \mathbf{n m}^{-2}\right)\end{array}\end{array}$ & $\underset{\left(\mathrm{m}^{2} \mathrm{~g}^{-1}\right)}{\mathrm{S}_{\mathrm{BET}}}$ & $\begin{array}{c}{ }^{\mathrm{b}} \mathbf{V} \mathbf{p} \\
\left(\mathrm{cm}^{3} \mathbf{g}^{-1}\right)\end{array}$ & $\begin{array}{c}\text { Acid } \\
\text { Strenght } \\
\mathrm{E}_{0}(\mathrm{mV})\end{array}$ \\
\hline$\gamma-\mathrm{Al}_{2} \mathrm{O}_{3}$ & -- & 211 & 0.55 & -- \\
\hline $\begin{array}{l}\mathrm{Re}(2,7) / \\
\gamma-\mathrm{Al}_{2} \mathrm{O}_{3}\end{array}$ & 2.7 & 174 & 0.30 & -93 \\
\hline $\mathrm{ZrO}_{2}$ & -- & 41 & 0.09 & -- \\
\hline $\mathrm{Re}(2,7) / \mathrm{ZrO}_{2}$ & 2.7 & 43 & 0.08 & -126 \\
\hline $\mathrm{SiO}_{2}$ & -- & 187 & 0.31 & -- \\
\hline $\operatorname{Re}(2,7) / \mathrm{SiO}_{2}$ & 2.7 & 124 & 0.23 & -185 \\
\hline $\mathrm{TiO}_{2}$ & -- & 54 & 0.09 & -- \\
\hline $\mathrm{Re}(2,7) / \mathrm{TiO}_{2}$ & 2.7 & 44 & 0.07 & -151 \\
\hline
\end{tabular}

${ }^{a}$ Specific area, BET Method

b Total pore Volume

The XRD are summarised in Figure 1 and shows the X-ray diffraction patterns for the ReOx catalysts along with the supports. It shows the presence of $\mathrm{ReO}_{3}$ and $\mathrm{ReO}_{4}^{-}$for the rhenium catalysts on $\mathrm{SiO}_{2}$ and $\gamma-\mathrm{Al}_{2} \mathrm{O}_{3}$. Figure 1 also shows that no diffraction peaks attributed to $\mathrm{ReO}_{3}$ and $\mathrm{ReO}_{4}^{-}$are found with the $\mathrm{ReOx}$ catalyst on $\mathrm{ZrO}_{2}$, suggesting that there is a high degree of dispersion of $\mathrm{ReOx}$ on the $\mathrm{ZrO}_{2}$. For the case of $\mathrm{ReOx} / \mathrm{TiO}_{2}$, only the species $\mathrm{ReO}_{4}^{-}$was detected, and were published previously 9 .

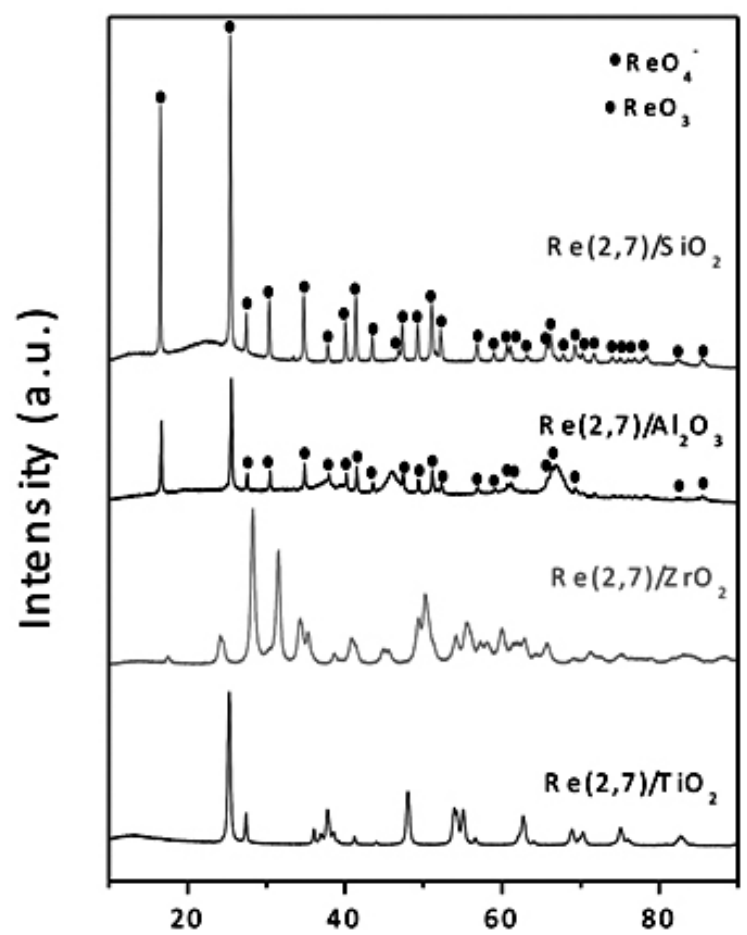

Figura 1: X-ray diffraction of : $\mathrm{ReOx} / \mathrm{SiO}_{2}, \mathrm{ReOx} / \gamma-\mathrm{Al}_{2} \mathrm{O}_{3}, \mathrm{ReOx} / \mathrm{ZrO}_{2}$ y $\mathrm{ReOx} / \mathrm{TiO}_{2}$ catalysts. ( $\mathrm{ReO}_{4}{ }^{-}$(JCPDS: 2101669 and $\mathrm{ReO}_{3}{ }^{2}$ (JCPDS: 00-241009)
Figure 2 shows the XPS results for the sulphide catalysts. For the catalysts supported on $\mathrm{SiO}_{2}$ and $\mathrm{TiO}_{2}$, a single fold containing $\mathrm{Re} 4 \mathrm{f}_{7 / 2}$ and $\mathrm{Re} 4 \mathrm{f}_{5 / 2}$ can be seen. This was assigned to species of $\operatorname{ReS}_{2}{ }^{9}$. For the catalysts supported on $\mathrm{Al}_{2} \mathrm{O}_{3}$ and $\mathrm{ZrO}$, two overlapping folds are seen; one assigned to $\mathrm{ReS}$ and the other the Re oxysulphide species ${ }^{10,11}$. The binding energy values are summarised in Table 2. The results indicate that the sulphurization of Re was slightly incomplete on $\mathrm{Al}_{2} \mathrm{O}_{3}$ and $\mathrm{ZrO}_{2}$ (close to $90 \%$ ). The results also suggest strong interaction between the $\mathrm{ReOx}$ and the supports. The $\mathrm{Re} / \mathrm{M}$ atomic ratio values $(\mathrm{M}=\mathrm{Si}, \mathrm{Ti}, \mathrm{Al}$ and $\mathrm{Zr})$ obtained by XPS, shows that the catalyst $\mathrm{ReS}_{2} /$ $\mathrm{TiO}_{2}$ has the highest $\mathrm{Re} / \mathrm{M}$ atomic ratio, followed by $\mathrm{ReS}_{2} / \gamma-\mathrm{Al}_{2} \mathrm{O}_{3}, \mathrm{ReS}_{2} / \mathrm{SiO}_{2}$ and finally $\mathrm{ReS}_{2} / \mathrm{ZrO}_{2}$. This trend suggests that $\mathrm{ReS}_{2}$ is more dispersed over the $\mathrm{TiO}_{2}$ support in agreement with XRD, while the ReS dispersion is low over the $\mathrm{ZrO}$; a similar result was observed previously ${ }^{12}$. The lowest dispersion showed by XPS for $\mathrm{ReS}_{2} / \mathrm{ZrO}_{2}$ catalyst is in opposite to the results obtained from XRD. These result suggested that the high Re dispersion obtained by XRD was modified in the sulphurization process leading to the formation of $\mathrm{ReS}_{2}$ aggregates.
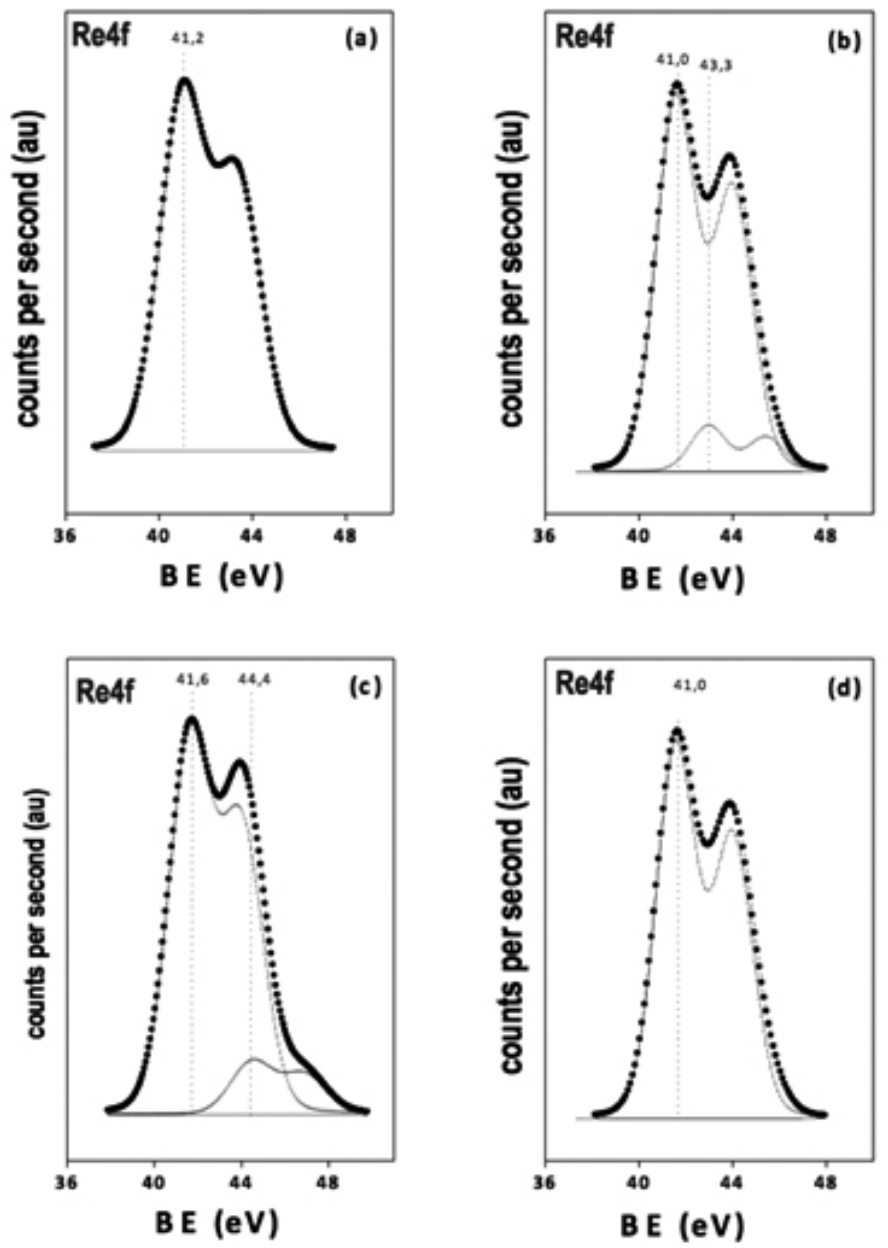

Figure 2: XPS of sulfides: a) $\mathrm{Re} / \mathrm{SiO}_{2}$, b) $\mathrm{Re} / \gamma-\mathrm{Al}_{2} \mathrm{O}_{3}$, c) $\mathrm{Re} / \mathrm{ZrO}_{2}$ and d) $\mathrm{Re} / \mathrm{TiO}_{2}$ catalysts. 
Table 2: XPS binding energies $(\mathrm{eV})$ and surface atomic ratios of sulphided catalysts.

\begin{tabular}{|c|c|c|c|c|}
\hline Catalysts & $\begin{array}{c}\text { M 2p } \\
\text { (Si, Al, Zr, Ti) } \\
(\mathbf{e . V .})\end{array}$ & $\begin{array}{c}\text { Re4f } \\
\text { (e.V.) }\end{array}$ & $\begin{array}{c}\text { S2p } \\
\text { (e.V.) }\end{array}$ & $\begin{array}{c}\mathrm{Re} / \mathrm{M} \\
\text { (Si, Al, Zr or Ti) }\end{array}$ \\
\hline $\mathrm{ReS}_{2}(2.7) / \mathrm{SiO}_{2}$ & 103.4 & 41.3 & 161.6 & 0.068 \\
\hline $\mathrm{ReS}_{2}(2.7) / \gamma-\mathrm{Al}_{2} \mathrm{O}_{3}$ & 74.5 & $\begin{array}{c}41.2(90) \\
42.3(10)\end{array}$ & 161.9 & 0.090 \\
\hline $\mathrm{ReS}_{2}(2.7) / \mathrm{ZrO}_{2}$ & 182.2 & $\begin{array}{c}41.7(89) \\
43.8(11)\end{array}$ & 162.2 & 0.053 \\
\hline $\mathrm{ReS}_{2}(2.7) / \mathrm{TiO}_{2}$ & 458.6 & 41.5 & 161.9 & 0.310 \\
\hline
\end{tabular}

3.2 Catalytic activity

Figure 3 shows the distribution of the products in steady state as a function of the $\operatorname{Re}(2,7)$ catalysts/support. It can be seen that for all catalysts, the quinoline is converted into 1,4-tetrahydroquinoline (1,4-THQ), decahydroquinoline (DHQ), orthopropylaniline (OPA), propylbenzene (PB) and propylcyclohexane $(\mathrm{PCH})$.

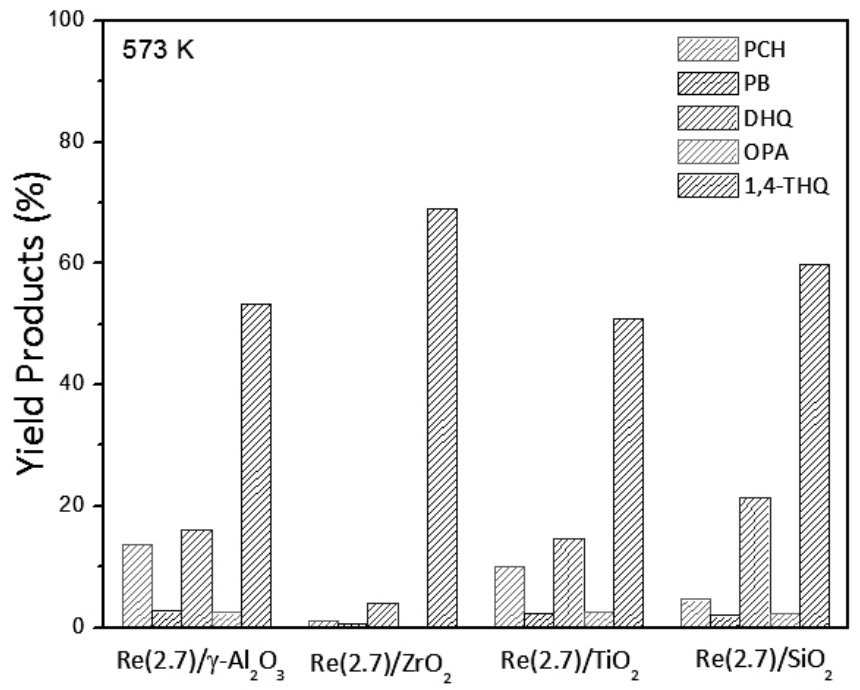

Figure 3: \% Formation of products using $\mathrm{ReS}_{2}$ on different supports.

The formation of these reaction products can be explained using the reaction scheme shown in Figure $4^{13}$. In general, all ReS catalysts showed low yields for dehydrogenated products $(\mathrm{PCH}$ and $\mathrm{PB}) \cdot \mathrm{Re}(2,7) / \mathrm{SiO}_{2}$ showed the highest level of formation of DHQ, suggesting that it has a highly hydrogenating nature. This was suggested previously by Sepulveda et al. ${ }^{14}$ in the HDS of 4,6-Dimethyldibenzothiophene and was attributed to the formation of Re with an oxidation between $0<\mathrm{x}<4$ under reaction conditions. The $\mathrm{Re}(2,7) / \mathrm{Al}_{2} \mathrm{O}_{3}$ showed the highest degree of formation of $\mathrm{PCH}$, which may be attributed to the higher acidic strength associated with this catalyst. The $\mathrm{ReS}_{2} / \mathrm{ZrO}_{2}$ showed the lowest yield for PCH and PB, with no OPA formation observed.

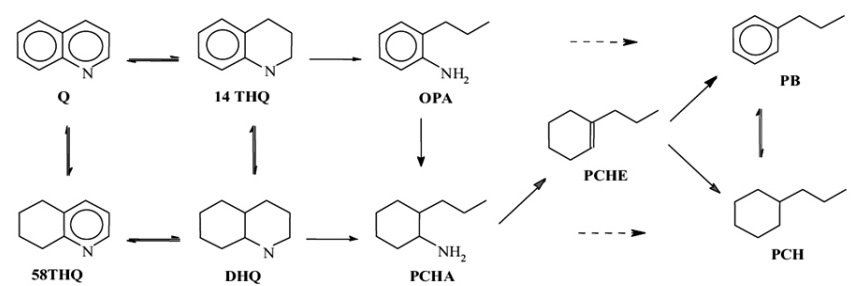

Figure 4: Reaction scheme for HDN of quinoline ${ }^{13}$

This may be attributed to the lower acidic strength of the catalysts, as shown in Table 3. However, it can also be related to the effect of the particle size of $\mathrm{ReS}_{2}$, in accordance with the XPS results, which showed that $\mathrm{Re}(2,7) / \mathrm{ZrO}_{2}$ had the lowest $\mathrm{Re} / \mathrm{Zr}$ atomic ratio. Unfortunately, measurements of HRTEM could not be taken on these catalysts, since under the beam of electrons the $\operatorname{ReS}_{2}$ sheets decompose into spherical structures ${ }^{12}$.

Figure 5 shows the intrinsic rates calculated in steady state for the $\operatorname{Re}(2,7)$ / supports. In this figure it can be seen that the activity depends on the support used and it increases in the following order: $\mathrm{Re}(2,7) / \mathrm{SiO}_{2}<\mathrm{Re}(2,7) / \gamma-\mathrm{Al}_{2} \mathrm{O}_{3}<$ $\mathrm{Re}(2,7) / \mathrm{ZrO}_{2}<\mathrm{Re}(2,7) / \mathrm{TiO}_{2}$. The higher activity may be attributed to a higher $\mathrm{Re} / \mathrm{M}$ surface ratio ( $\mathrm{Si}, \mathrm{Al}, \mathrm{Zr}$ and $\mathrm{Ti}$ ) obtained by XPS for the $\operatorname{Re}(2,7) / \mathrm{TiO}$. However, the trend obtained for the other catalysts cannot be correlated with the dispersion measurements relative to Re obtained by XPS, the degree of sulphurization of the $\mathrm{ReS}_{2}$ and the acidic strength of the catalysts, suggesting that the support is modifying the electron properties of the $\mathrm{ReS}_{2}$.

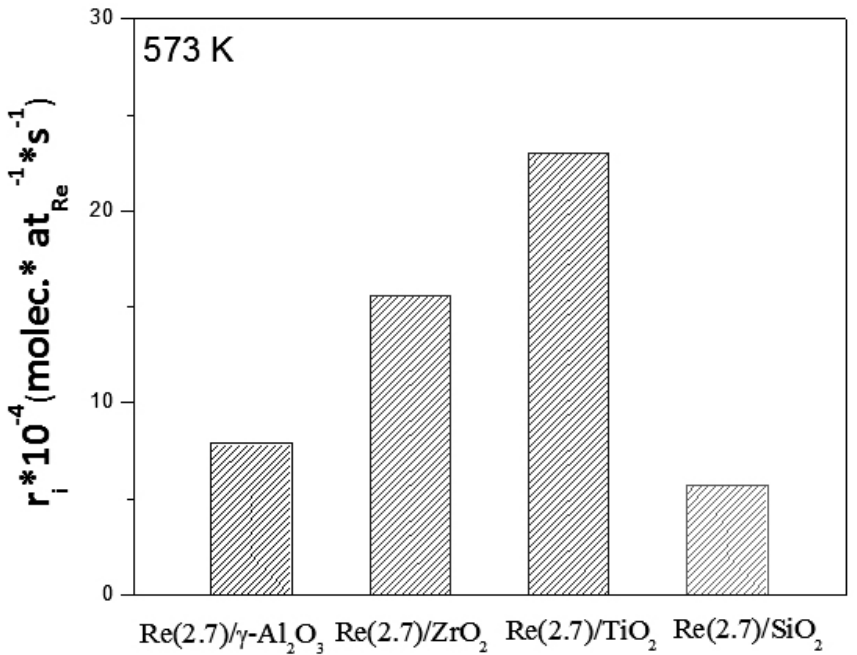

Figure 5: Catalytic intrinsic activity of $\mathrm{ReS}_{2}$ on the different supports

Figure 6 shows the effect of adding $\mathrm{CS}_{2}$ on the quinoline conversion using the $\mathrm{ReS}_{2}$ catalysts supported on $\gamma-\mathrm{Al}_{2} \mathrm{O}_{3}$. It can be seen that the addition of $\mathrm{CS}_{2}$ at a concentration of $2.5 \% \mathrm{v} / \mathrm{v}$ increases the activity in comparison to the absence of $\mathrm{CS}_{2}$ in the feed. This may be because the carbon sulphide avoids the deactivation of the active sites. However, at the higher concentration of $\mathrm{CS}_{2}$, the quinoline conversions decrease, as observed previously in the conversion of guaiaco ${ }^{15}$. This can be explained by the fact that the $\mathrm{H}_{2} \mathrm{~S}$ formed from the $\mathrm{CS}_{2}$ leads to competitive adsorption with the quinoline on the active sites of the catalyst, thus decreasing the sites accessible for quinoline conversion. 


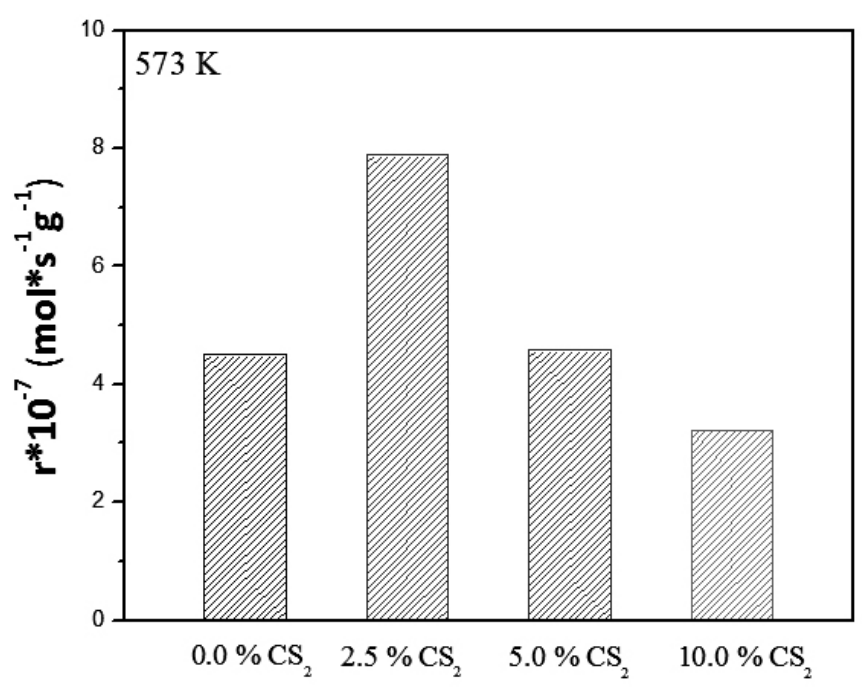

Figure 6: Catalytic activity obtained using $\mathrm{ReS}_{2} / \gamma-\mathrm{Al}_{2} \mathrm{O}_{3}$, and feed modified with the addition of: $0.0 \% \mathrm{CS}_{2}, 2.5 \% \mathrm{CS}_{2}, 5 \% \mathrm{CS}_{2}$ and $10 \% \mathrm{CS}_{2}$.

Figure 7 shows the distribution of reaction products at different $\mathrm{CS}_{2}$ content on the $\mathrm{ReS}_{2} / \mathrm{TiO}_{2}$. It can be seen that by adding $\mathrm{CS}_{2}$ to the feed, the yield of denitrogenated products ( $\mathrm{PCH}$ and $\mathrm{PB}$ ) increases considerably and it is not proportional to the change in conversion.

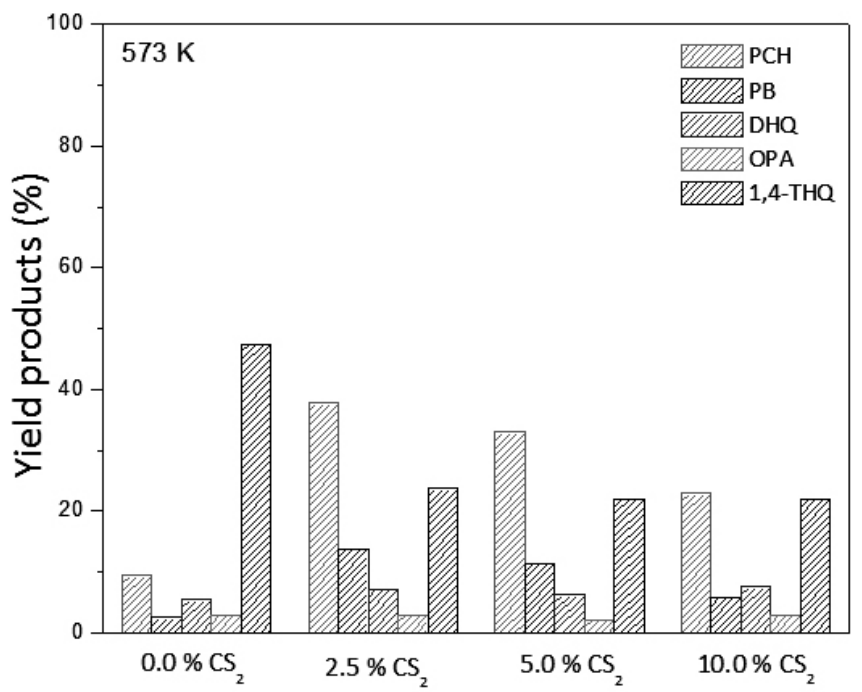

Figure 7: Product formation using $\mathrm{ReS}_{2} / \gamma-\mathrm{Al}_{2} \mathrm{O}_{3}$, and a feed modified with the addition of: $0.0 \% \mathrm{CS}_{2}, 2.5 \% \mathrm{CS}_{2}, 5 \% \mathrm{CS}_{2}$ and $10 \% \mathrm{CS}_{2}$.

This change in the distribution suggests that the $\mathrm{H}_{2} \mathrm{~S}$ may be modifying the active sites on the $\mathrm{ReS}_{2}$, decreasing the hydrogenation sites and favouring hydrogenolysis sites. However, Vrinat et al. ${ }^{16}$ demonstrated the existence of a single type of active site on sulphide catalysts. Therefore, the increase in $\mathrm{N}$-free products in the presence of $\mathrm{H}_{2} \mathrm{~S}$ on $\mathrm{ReS}_{2}$ may be attributed to the fact that $\mathrm{H}_{2} \mathrm{~S}$ is decreasing the metal nature of $\mathrm{ReS}_{2}$, diminishing its hydrogenating nature. In other words, in the absence of $\mathrm{CS}_{2}$ the $\mathrm{ReS}_{2}$ tends to form Re species with oxidation status of $0<\mathrm{x}<4$, thus favouring hydrogenation sites, while in the presence of $\mathrm{CS}_{2}$, the stability of $\mathrm{ReS}_{2}$ is favoured, leading to a higher percentage of denitrogenated products.

\section{CONCLUSIONS}

The results of this study show that the support affects the catalytic activity of $\mathrm{ReS}_{2}$. The highest activity was obtained on $\mathrm{TiO}_{2}$ and was attributed to the highest $\mathrm{ReS}_{2}$ dispersion. For the activity on the other supports, no direct correlation was found with the structural properties of the $\mathrm{ReS}$. The addition of $2.5 \% \mathrm{v} / \mathrm{v} \mathrm{CS}$ increased the quinoline conversion. This increase was attributed to the improved stability of the $\mathrm{ReS}_{2}$. The distribution of the products suggests that quinoline conversion in the presence of $\mathrm{H}_{2} \mathrm{~S}$ has a different reaction mechanism than in the absence of $\mathrm{H}_{2} \mathrm{~S}$. The effect of $\mathrm{H}_{2} \mathrm{~S}$ shows that high concentrations inhibit the reaction due to adsorption competition with the quinoline.

\section{ACKNOWLEDGEMENTS}

The authors gratefully acknowledge Fondecyt Project $N^{\circ} 1130749$ and 1140808, along with PFB-27 for financial support.

\section{REFERENCES}

1.- L.H. Ding, Y. Zheng, Z.S. Zhang, Z. Ring, J.W. Chen, Appl. Catal. A. 319 (2007) 25-37.

2.- G.C. Laredo, P.M. Vega-Merino,F. Trejo-Zárraga, J. Castillo, Fuel Process. Technol. 106 (2013) 21-32.

3.- D. Dong, S. Jeong, F.E. Massoth, Catal. Today. 37 (1997) 267-75.

4.- V. Rabarihoela-Rakotovao, S. Brunet, G. Berhault, G. Perot, F. Diehl, Appl. Catal. A 167 (2004) 17-25.

5.- A. Stanislaus, A. Marafi, M.S. Rana, Catal. Today. 153 (2010) 1-68.

6.- S. Eijsbouts, V.H.J. De Beer, R. Prins, J. Catal 127 (1991) 619-623.

7.- Escalona N, Vrinat M, Laurenti D, Gil Llambías F. J., Appl. Catal. A 322 (2007) 113-124.

8.- R. Cid, G. Pecchi, Appl. Catal. 14 (1985) 15-21.

9.- R. Bassi, M. Villarroel, F.J. Gil, P. Baeza, .L. Fierro-García, N. Martinez. P Olivera, K.Leiva, N. Escalona, J. Chil. Chem. Soc., 61 (2016) 3013 3019.

10.- K. Leiva, N. Martinez, C. Sepulveda, R. García, C.A. Jiménez, D. Laurenti, M. Vrinat, C. Geantet, J.L.G. Fierro, I.T. Ghampson, N. Escalona, Applied Catalysis 490 (2015) 71-79

11.- N. Escalona, J. Ojeda, R. Cid, G .Alves, A. López Agudo, J.L.G Fierro, F.J.Gil Llambías, Appl. Catal. 234 (2002) 45-54

12.- D. Laurenti, K.T. Thoa, N. Escalona, L. Massin, M. Vrinat, F.G. GilLlambias, Catl.Today 130 (2008) 50-55.

13.- S. Chouzier, M. Vrinat, T. Cseri, M. Roy-Auberger, P. Afanasiev, Appl Catal A 400 (2011) 82-90.

14.- C. Sepulveda, R. García, N. Escalona, D. Laurenti, L. Massin, M. Vrinat, Catal Lett 141 (2011) 987-995.

15.- P.E. Ruiz, K. Leiva, R. Garcia, P. Reyes, J.L.G. Fierro, N. Escalona, Appl. Catal. A 384 (2010) 78-83.

16.- M. Vrinat, R. Bacaud, D. Laurenti, M. Cattenot, N. Escalona, S. Gamez, Catal. Today 107 (2005) 570-577. 